Bulletin of the Natural History Museum, 2017, 10: 29-41.

Received 11 Jun 2017; Accepted 18 Nov 2017.

doi:10.5937/bnhmb1710029R

UDC: $562 / 569: 551.782 .13(497.11)$

Original scientific paper

\title{
THE MIOCENE FOSSILIFEROUS SITES OF THE AVALA MT. (BELGRADE AREA, SERBIA) AND THEIR IMPORTANCE
}

\author{
LJUPKO RUNDIĆ*, SLOBODAN KNEŽEVIĆ \\ University of Belgrade, Faculty of Mining and Geology, Kamenička 6, \\ 11000 Belgrade \\ e-mails: ljupko.rundic@rgf.bg.ac.rs; knezevic.slobodan@gmail.com
}

Sediments of the Middle and Late Miocene (about 16-5.3 Ma) are widespread in the area of Avala Mt. and its vicinity. As a rule, they contain abundant and diverse fossilized representatives of macro and micro fauna that existed during the Middle Miocene in the Paratethys (Rakovica stream, Leštane, Torlak, Kumodraž, Zavojnica River valley, Vrčin). Rich fossil assemblages consist mainly of algae, foraminifers, ostracods, mollusks, corals, bryozoans, echinoderms and crabs as well as otoliths and jaws of fish. Although marine organisms are not found in the Late Miocene sediments, there are numerous and diverse representatives of endemic fauna from the ancient Lake Pannon. The most important sites of Middle and Late Miocene deposits are located at the Torlak hill, in Vrčin, Zuce, Karagača, Beli Potok and Konopljište. They are significant not only for the stratigraphic-paleontological studies, paleogeographic and geodynamic reconstructions during the Miocene but also as valuable geodiversity and geoheritage objects.

Key words: fossiliferous sites, Miocene, Avala Mt., Paratethys, Lake Pannon.

\section{INTRODUCTION}

Avala, a small mount south of Belgrade, belongs to the belt known as the "Šumadija Mesozoic Ridge", which separates the area of two Tertiary basins - the Velika Morava Basin on the east and the Kolubara-Tamnava 
Basin on the west (Marović \& Knežević 1985). It is built from Triassic and early Upper Jurassic sedimentary rocks within the Jurassic ophiolite melange (Bragin et al. 2011), as well as Cretaceous sediments and ultramafites (serpentinite and dunite peridotite). In addition, there is also a minor occurrence of dacite-andesitic volcanic rocks. Dimitrijević (1931) assumed that laccolite of the dacite-andesitic magma has been formed in its interior during the Paleogene. According to the regional geotectonic classification of Serbia, the older Mesozoic units in this area belong to the Tethys oceanic domain, i.e. the Vardar zone in the wider sense (Karamata 2006, Toljić 2006, 2016) and the Sava zone (Schmid et al. 2008). The Miocene sediments were deposited transgressively and discordantly over older rocks and have made the infill of the Paratethys epicontinental sea (Stevanović 1980) or its Late Miocene successor - the Lake Pannon (Stevanović 1951, 1958, 1985, Krstić 1972, 1973, 1985, Rundić et al. 2010, 2011, 2015, 2017). The Neogene (Miocene) sediments, rich in various fossils, have widespread distribution in the area of Avala and its vicinity.

It is believed that during the Middle Miocene, the Avala Mt. was the central part of a large island in the southeastern part of the Central Paratethys. In the early Middle Miocene (Badenian) this island, known in literature as the Avala land or the Great Avala Island (Eremija 1977a, 1977b, 1987, Stevanović 1980) had NNW-SSE direction and extended from Belgrade in the north toward Avala and Kosmaj in the south. At the beginning of the late Middle Miocene (Sarmatian), tectonic movements divided this land into two islands - Avala in the north, and Kosmaj in the south, while the tectonic "Sopot channel" which was formed between them (Marović \& Knežević 1985, Marović et al. 1995, 2007). In addition, a series of smaller islands have also appeared as relicts of the Great Avala Island. In the Upper Miocene (Pannonian and Pontian sensu Stevanović 1985), as a consequence of the tectonic uplift of the Carpathians and the isolation of the Pannonian Basin, a sedimentation cycle started within the new paleogeographic entity - the Lake Pannon (Ter Borgh et al. 2013). During the Pontian, a tectonic depression known as the Beli Potok Trough has been formed at the northern edge of Mt. Avala (Marović \& Knežević, 1985, Knežević, 1989, 1990, Rundić et al., 2017). It was a small brackish lake-bay, connected with the larger one in the area of the present-day Grocka and Smederevo (Marović et al. 2007). At the end of Pontian, the progradation processes affected the reduction of the Lake Pannon in this area and its final infill (Magyar et al. 2013).

All these paleogeographic changes are well documented in the area of Mt. Avala by collections of fossils, including algae, foraminifers, ostracods, molluscs, corals, bryozoans, echinoids, annelids, crabs and plants. Fossil collecting in the area, of which the first date to the end of the 19th century 
and the beginning of the 20th century, is still under way. The earliest written records date back to Pavlović (1890, 1893, 1903, 1922, 1923), Laskarev (1924) and Laskarev et al. (1931). Significant contributions in the field of stratigraphic-paleontological importance of fossiliferous sites, geodiversity and geoheritage of the Belgrade area and reconstruction of the Neogene geodynamics and paleogeography of this area have been provided recently (Bradić et al. 2015, Schwarzhans et al. 2015, Ganić et al. 2016, Rundić, 2010, Rundić et al. 2010, 2017).

\section{STRATIGRAPHIC AND PALEONTOLOGICAL CHARACTERISTICS OF THE MIOCENE DEPOSITES}

Fossiliferous sediments that occurred in the area of Mt. Avala provide evidence of the existence of the Central Paratethys ("Pannonian Sea") and the Lake Pannon. Several sites of international scientific significance for the Neogene stratigraphy and correlation within the Paratethys terrains (Stevanović 1985) are presented, together with a short history of research, lithology and fossils content (Figure 1).

\section{EARLY MIDDLE MIOCENE - THE BADENIAN}

The Badenian marine sediments are well documented in the villages Kumodraž, Leštane, Mali Mokri Lug and Kaludjerica. The most important sites include deposits outcropped in the Rakovica stream (Torlak hill) and the Leštane stream (Leštane village).

Rakovica stream ("Rakovički Potok", Figures $1 \& 2 a$ ) is located at the north-western foothills of Torlak, on the left bank of the Rakovica stream. In Serbia, this site represents a classic locality of the sandy facies of the Middle Miocene (Badenian), rich in marine fossils: gastropods, bivalves, foraminifers, ostracodes, algae, bryozoans, echinoids, otoliths, crabs, and others. It had provided an in situ polygon for training a new generation of paleontologists and geologists. The eminent Serbian naturalist Josif Pančić brought fossils collected from the "Rakovica stream" in the second half of the 19th century to the respected Austrian paleontologist M. Hoernes, who confirmed that this fauna, also known from the Vienna Basin, referred to the "II Mediterranean" (earlier name for the Badenian). Fossils from this site have been the subject of interest of many researchers (P. Pavlović, M. Luković, P. Stevanović, M. Eremija). Eremija (1987) considered that sandy facies from the Rakovica stream represented depositional environment of a marine beach. 
32 Rundić, Lu., KNEŽEviĆ, S.: Miocene Fossiliferous sites of THE Avala MT.

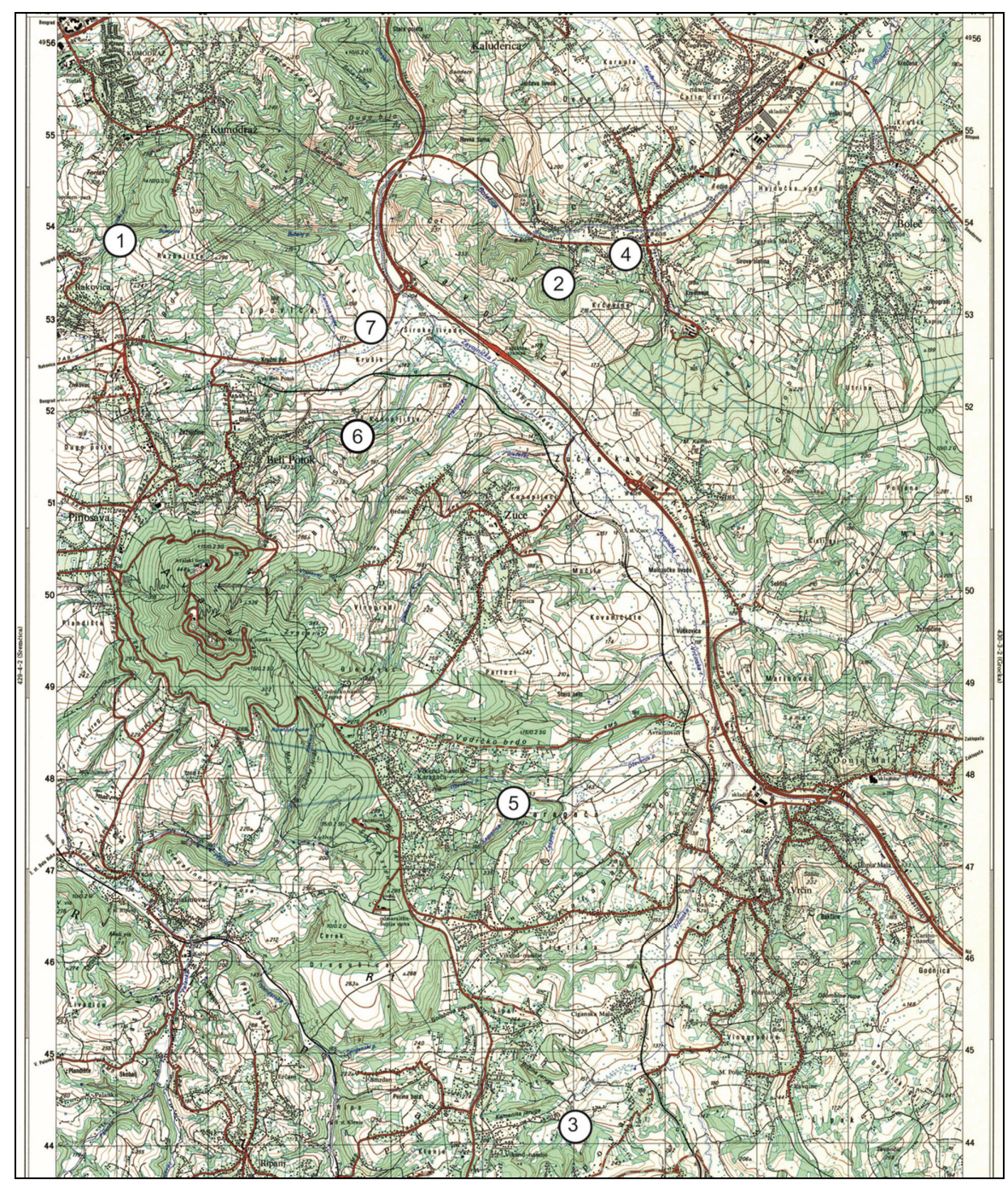

Fig. 1. - Topographic map 1: 25.000 shows the location of investigated fossiliferous sites in the Avala area: 1-Rakovica stream, 2-Leštane stream, 3-Vrčin (Kasapovac), 4-Leštane (Bolečica River), 5-Karagača stream, 6-Beli Potok (Konopljište stream), 7-Beli Potok ("Circular road")

Having analysed the traces of drilling predation on mollusks, Ganić and others (2016), processed a total of 1617 gastropod and 684 bivalve shells (e. g. Acteocina lajonkaireana, Athleta rarispina, Ancila glandiphormis, Natica millepunctata, Retusa truncata, Murex granularis, etc.). Numerous foraminifers, ostracodes, and fish otoliths indicate marine-brackish depositional environment at the end of Badenian. Within the microfauna, dominant representatives are: Ammonia beccarri, Elphidium crispum, 
Borelis mello, Cletocythereis haidingeri, Cnestocythere truncata, Costa edwardsii (Bradić et al. 2015, Schwarzhans et al. 2015, Rundić et al. 2015, 2017). Fossils gathered from the Rakovica stream (Figure 2b) are housed today in museums and other collections in Serbia (the Natural History Museum in Belgrade, the Stratigraphic-Paleontological collection/Faculty of Mining and Geology, Belgrade University and the Serbian Geological Survey) and abroad.

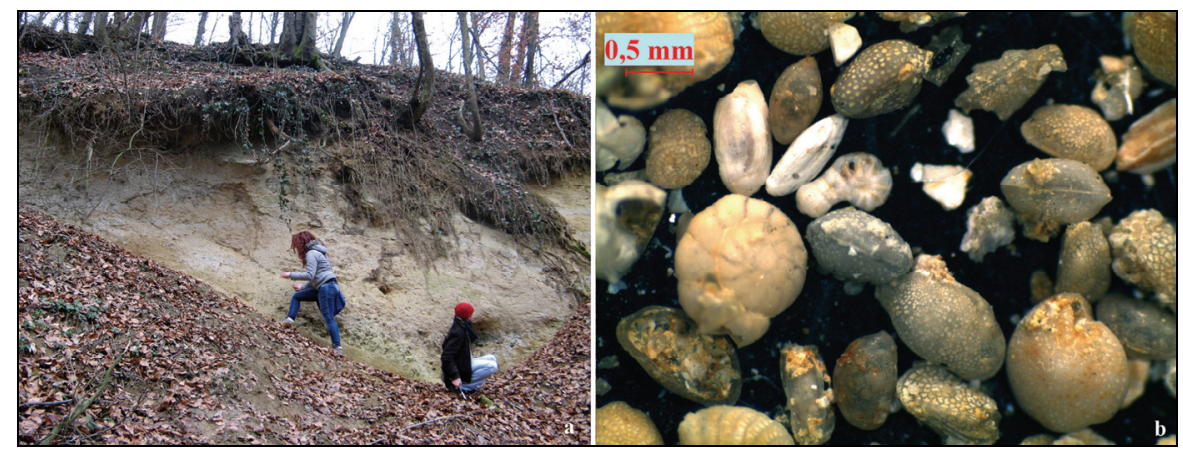

Fig. 2. - a) Rakovica stream section, b) well-preserved foraminifers and ostracods (detail) (after Rundić et al. 2015)

Leštane (Figure 1). Several outcrops of the Badenian fossiliferous layers are exposed along the left bank of the middle course of the Leštane stream. They correspond mostly to the "Leitha limestone" (named after the Leitha Mt. in Lower Austria). Lithologically, sediments are very similar to the Miocene limestones that occurred in the center of Belgrade (Tašmajdan and Kalemegdan), but they belong to different bioherm-structure produced by the life activity of reefal organisms, including calcareous algae, foraminifers, bryozoans, sponges and molluscs. Sediments often contain macrofaunal fossils such as massive bivalves (Chlamys latissima, Flabelipecten besseri, Glycimeris pilosus), sculptured gastropods, echinoids, and rarely corals. These deposits were used previously as a construction material.

\section{LATE MIDDLE MIOCENE - THE SARMATIAN}

In the vicinity of Avala, the Sarmatian sediments are widespread in comparison with those of the Badenian. They are found in several sites, including Vrčin, Leštane, Boleč, Kumodraž and Ripanj. Due to the abundance of fossils, particularly instructive are the outcrop Kasapovac near Vrčin and a section exposed on the right bank of the Bolečka River in Leštane.

Vrčin (Kasapovac, Figure 1). Sarmatian sediments occur along the banks of streams and watercourse in the Vrčin village near Belgrade. They 
consist of marls, marly sandstones and limestones rich in fossilised mollusks. Particularly frequent are representatives of species Mactra vitaliana eichwaldi, Irus gregarious, Cerastoderma vindobonense, $C$. latisulcum, Pirenella picta, P. disjuncta and Dorsanum duplicatum. Today, this area is quite urbanised and once well-exposed outcrops are now difficult to access for research purposes.

Leštane (the right bank of Bolečica River, Figures $1 \& 3$ a, b). Well-preserved layers of the Sarmatian deposits are occurred along the "Circular road", on the right bank of Bolečka River. They contain numerous mollusk fossils, such as Ervilia dissita, Cerastoderma vindobonense, Mactra vitaliana eichwaldi, Modiolus incrassatus, Pirenella picta, P. disjuncta, Gibbula sp. Although the site is easily accessible for research, it is threatened by expansive spreading of suburb areas.

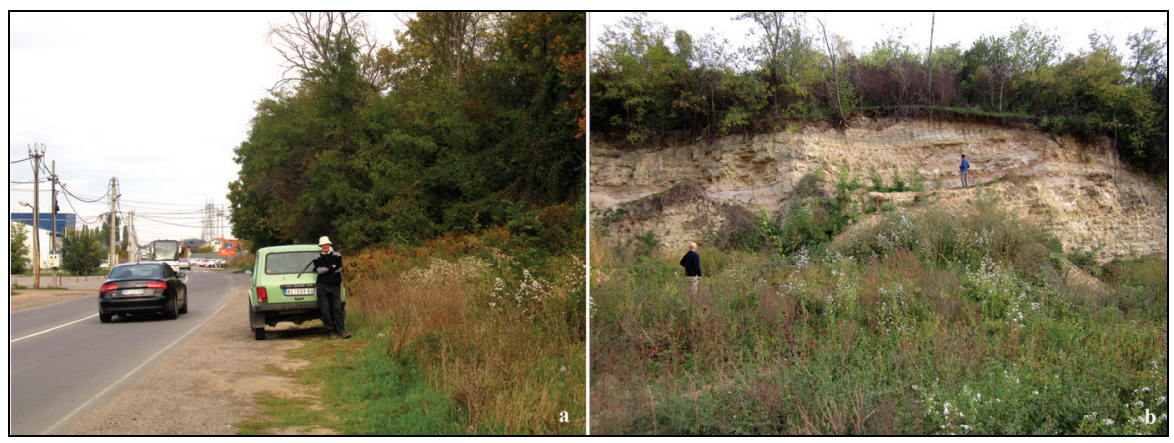

Fig. 3. - a) "Circular road" in Leštane, b) Sarmatian fossiliferous carbonates (photo: M. Radonjić)

\section{EARLY LATE MIOCENE - THE PANNONIAN (sensu STEVANOVIĆ, 1985)}

The Pannonian sediments have the greatest distribution of all Miocene deposits in the Avala area (Stepanović 1938). They are mainly exposed in the villages Ripanj, Vrčin, Zuce, Pinosava, Kumodraž and Resnik. Well preserved fossils are investigated at several sites within the sections Karagača and Slatina (Vrčin), Ramaća (Ripanj) and Zuce.

Vrčin-Karagača stream (Figures $1 \& 4 a$ ). One of the best studied profiles of Upper Pannonian fossiliferous deposits is located on the right bank of Karagača stream near Vrčin (Stevanović 1958, Rundić 2010). It includes sandy and gravel layers that transgressively overlay hydrothermally altered serpentinite. At this location, an enormous sand-pit opened up during the construction of the Belgrade-Požarevac railway in the $1920 \mathrm{~s}$. Malacologist P. Pavlović (1929) identified representatives of 102 mollusc species as well as two new genera, collected from the Pannonian sediments. Paleontological analysis indicates that massive molluses predominate and 
include species Congeria subglobosa gigantea, C. pancici, C. spathulata, C. koshanini, Limnocardium tucani, L. viquneli, Melanopsis rugosa. From the scientific point of view, new endemic gastropod forms and subspecies such as Melanopsis impressa pyrulaeformis and Melanopsis vindobonensis var. karagacensis (Figure 4b) are particularly significant. In addition, Krstić $(1972,1973,1985)$ also discovered numerous fossilized ostracodes. In the stratigraphic division of Miocene in the Pannonian Basin, the Karagača site is recognised as the stratotype of the late Upper Pannonian the Serbian substage (Stevanović 1985). In comparison with the other sites, the area of Karagača stream is not inhabited, but its visibility is partly concealed by vegetation; in this way, this site is protected from unwanted visitors.

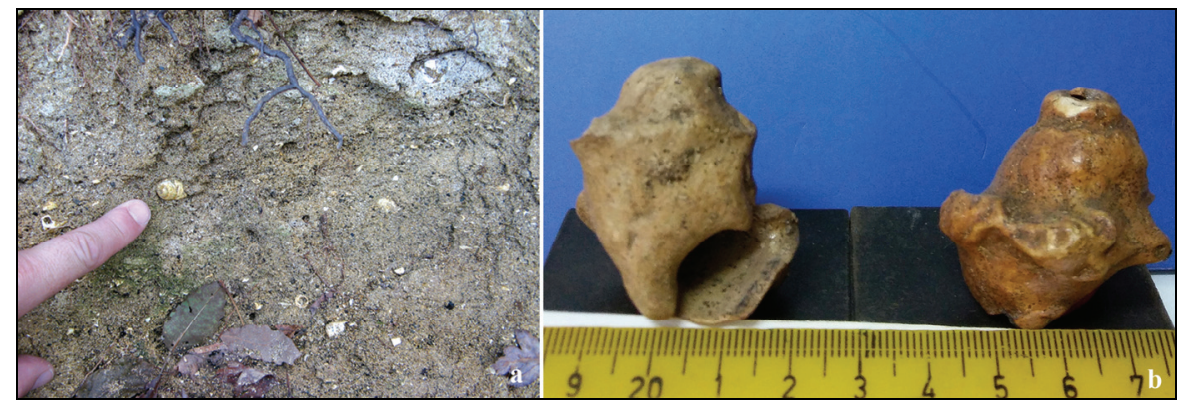

Fig. 4. - a) Endemic mollusks from Karagača stream, b) gastropod Melanopsis vindobonensis var. karagačensis (collection of P. Pavlović, Department of Regional Geology/ Faculty of Mining and Geology, Belgrade University) (photo: Lj. Rundić)

THEUPPER PART OF LATEMIOCENE-PONTIAN (sensu STEVANOVIĆ, 1985)

Outcrops of the youngest Miocene (Pontian) deposits are located in the Beli Potok village. According to Stevanović (1951), this area represents an asymmetric tectonic trench that is separated by a large fault from the "Torlak horst". On its southern part, the Pontian deposits transgressively overlay the Cretaceous "paleo-relief” (Eremija 1977a, 1977b, Knežević, 1989, Rundić et al. 2017). Fossiliferous sites in the Beli Potok village are well-known for collected mollusc fauna, whose representatives are important for the biostratigraphy of Pontian in Serbia. The following localities are pointed out: the Konopljište stream, the railway tunnel Belgrade-Mala Krsna, and several outcrops located above the "Circular road". During the past decades, fossils of brackish and lacustrine ostracodes were also gathered (the papers of $\mathrm{N}$. Krstić and Lj. Rundić in references).

Beli Potok (Konopljište stream, Figure 1). The Lower Pontian fossiliferous sediments occurred at the beginning of the last century along the 
Konopljište stream (the spring Erska česma, Beli Potok village). At the time of first investigations, there was an outcrop built by conglomerates, corresponding to the littoral zone of the Lake Pannon (Pavlović 1931, Stevanović 1951), which contained representatives of mollusc species such as Melanopsis rugosa, M. defensa, Congeria ungulacaprae, C. balatonica, C. thorn, C. vuki, Limnocardium banaticum, L. ornatum. Based on the paleontological analyses and comparison with fossils from the Lower Pontian sediments identified at the Radmanesti locality in Romania (Stevanović 1951), the Konopljište stream was assigned the facial stratotype for the littoral development of Lower Pontian in Serbia (Knežević 1987). However, this fossiliferous exposure was buried in the late 1970s by a huge landfill that inhibited access to it. A lateral extension of conglomerates with fossilised fauna (mainly bivalve species Congeria ungula caprae) was discovered through additional field survey in the area, about 100 meters away from the previous site.

Beli Potok (the entrance to the railway tunnel). The Upper Pontian deposits were discovered during the construction of the railway tunnel Belgrade-Mala Krsna between two World Wars. Fossils found within grey marly silts were studied by Pavlović (1923) and Stevanović (1951). They mainly contain representatives of mollusks Congeria rhomboidea, $C$. croatica, C. zagrabiensis, Limnocardium zagrabiense, Limnocardium mayeri, Valenciennius reussi. In addition, paleofloral remains were also collected from this site and investigated by botanist P. Černjavski. After the completion of the railway tunnel, only a tiny section of the once enormous profile remains visible today.

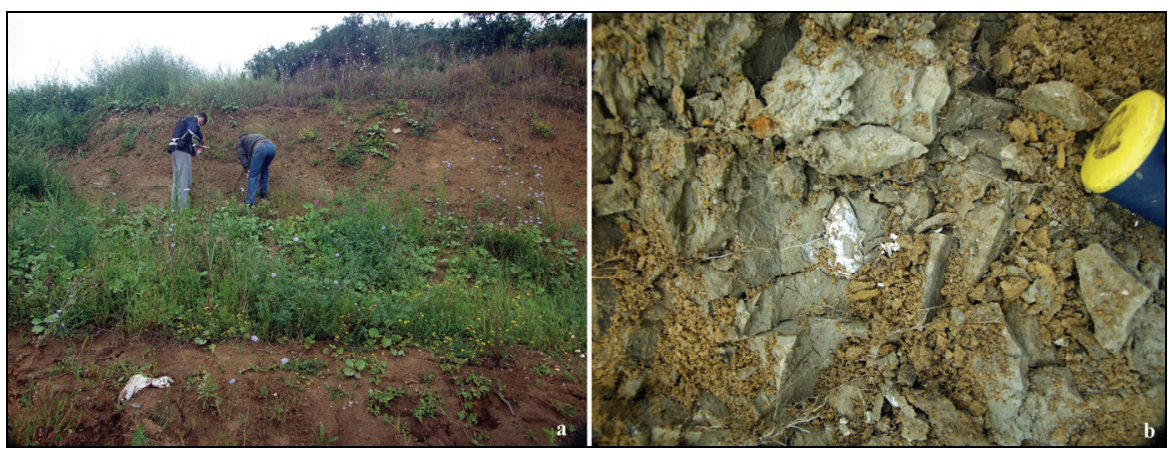

Fig. 5. - a) Upper Pontian marly and sandy silts from Beli Potok section ("Circular route"), b) bivalve Congeria sp. (photo: Lj. Rundić)

Beli Potok ("Circular road" to Highway E75, Figures $1 \& 5$ a, b). The Upper Pontian marly silts, silty sands and clays also occur at the base of Torlak hill. They comprise abundant fossilised molluscs (Congeria croatica, Congeria zagrabiensis, C. rhomboidea, Limnocardium zagrabiense, L. 
mayeri) and ostracodes (Cyprideis triangulata, Hemicytheria josephinae, H. dubokensis, Bakunella dorsoarcuata, Camptocypria zalanyi, Camptocypria flectimarginata, Amplocypris bacevicae, Cypria tocorjescui, Loxoconcha schweyeri) (Rundić et al. 2017).

\section{CONCLUSIONS}

The Miocene sediments are extensively distributed in the foothill of the Avala Mt. and its vicinity. In the Middle and Late Miocene (about 16-5.3 $\mathrm{Ma}$ ) this area was an island, first in the Paratethys domain (Rakovica stream, Leštane, Torlak, Kumodraž, Zavojnica River valley, Vrčin) and subsequently within the Lake Pannon (Torlak hill, Vrčin, Zuce, Karagača, Beli Potok and Konopljište).

All the presented localities are characterised by a great variety of fossilised macro and micro fauna, which indicates favourable living conditions and a strong influence of thermal water that existed in the area at that time (relatively shallow and warm environment). The appearance of thermal water increased not only the average water temperature but also the percent of mineralisation. It was reflected in the occurrence of numerous endemic molluscs with massive and recrystallised shells, particularly within the Karagača stream and Beli Potok sections.

Both immoveable (fossiliferous sites) and moveable (collections of fossils) geoheritage objects are significant in terms of geological and paleontological research, paleogeographic and paleoecological studies, reconstruction of geodynamic evolution of Paratethys and Lake Pannon during the Miocene, as well as presentation and promotion of geodiversity and geoheritage in the wider area of Belgrade.

\section{REFERENCES}

Bradić, K., Rundić, Lj., Ganić, M. (2015): Badenian-Sarmatian otoliths from the Rakovica Stream (Miocene of Belgrade city area). In: I Kongres geologa u Bosni i Hercegovini sa međunarodnim učešćem, Tuzla, 21-23.10.2015: 41-42. - Udruženje/Udruga geologa u Bosni i Hercegovini, Knjiga sažetaka.

Bragin, N. Y., Bragina, L. G. N., Djerić, N., Toljić, M. (2011): Triassic and Jurassic radiolarians from sedimentary blocks of ophiolite mélange in the Avala Gora area (Belgrade surroundings, Serbia). - Stratigraphy and Geological Correlation 19(6): 631-640.

Dimitrijević, B. (1931): Avala, petrografsko-mineraloška studija sa geološkom kartom 1: 50 000. - Srpska kraljevska akademija, posebna izdanja 85: 1-150. [in Serbian] 
Eremija, M. (1977a): Miocen u oblasti ekshumiranog mezozojsko-serpentinskog paleoreljefa od Rakovice do Ripnja. - In Petković, K. (Ed.) Geologija Srbije. Stratigrafija II/3: 145-154. [in Serbian]

Eremija, M. (1977b): Pliocen belopotočke rov-sinklinale. - In: Petković, K. (ed.): Geologija Srbije. Stratigrafija II/3: 178-181. [in Serbian]

Eremija, M. (1987): Badenski kat. - In: Andjelković, M. (ed.): Geologija šire okoline Beograda. I Geologija i geodinamika: 151-172. - Zavod za Regionalnu geologiju i paleontologiju Rudarsko-geološkog fakulteta Univerziteta u Beogradu. [in Serbian]

Karamata, S. (2006): The geological development of the Balkan Peninsula related to the approach, collision and compression of Gondwanan and Eurasian Units. - In: Robertson, A. H. F., Mountrakis, D. (eds.): Tectonic Development of the Eastern Mediterranean Region: 155-178. - Geol. Soc. Spec. Publ. 260, London.

Knežević, S. (1987): Pontski kat. Geologija šire okoline Beograda. I Geologija i geodinamika: 222-247. - Zavod za Regionalnu geologiju i paleontologiju Rudarsko-geološkog fakulteta Univerziteta u Beogradu. [in Serbian]

Knežević, S. (1989): Prinove iz ponta belopotočkog rova. - Geološki anali Balkanskoga poluostrva 53: 373-384. [in Serbian]

Knežević, S. (1990): Prilog poznavanju neogenih sedimenata okoline Beograda (stratigrafski prikaz bušotine KGK-16 kod Vrčina). - Geološki anali Balkanskoga poluostrva 54: 373-384. [in Serbian with English summary]

Krstić, N. (1972): Rod Candona (Ostracoda) iz kongerijskih slojeva južnog dela Panonskog Basena. - Srpska akademija nauka i umetnosti, Odeljenje prirodno-matematičkih nauka, posebna izdanja 39. [in Serbian with English summary]

Krstić, N. (1973): Biostratigrafija kongerijskih slojeva okoline Beograda na osnovu ostrakoda sa opisom vrsta roda Amplocypris. - Institut za geološka i rudarska istraživanja i ispitivanje nuklearnih i drugih sirovina, posebna izdanja 4. [in Serbian with English summary]

Krstić, N. (1985): Ostracoden im Pannonien der Umbegung von Belgrad. - In: Papp, A., Jambor, A., Steininger, F. F. (eds.): Pannonien M6, Chronostratigraphie und Neostratotypen, Miozän der Zentralen Paratethys: 103-143. Akadémiai Kiadó, Budapest, 7.

Laskarev, V. (1924): Sur les équivalents du Sarmatien supérieur en Serbie. -In: Vujević, P. (ed.): Recueil de traveaux ofert a M. Jovan Cvijic par ses amis et collaborateurs: 73-85. - Državna štamparija Kraljevine SHS, Beograd.

Laskarev, V., Petković, V. Luković, M. (1931): Geološka karta okoline Beograda 1: 25.000. - Geološki institut Kraljevine Jugoslavije, Beograd.

Magyar, I., Radivojević, D., Sztanó, O., Synak, R., Ujszászi, K., Pócsik, M. (2013): Progradation of the paleo-Danube shelf margin across the Pannonian Basin during the Late Miocene and Early Pliocene. - Global and Planetary Change 103: 168-173.

Marović, M., Knežević, S. (1985): Neotektonika jednog dela Šumadije i severozapadne Srbije. - Geološki anali Balkanskoga poluostrva 49: 221-247. [in Serbian with English summary] 
Marović, M., Djoković, I., Knežević, S., Rundić, Lj., Mitrović, S., Šumar, M., Toljić, M. (1995): Principal geodynamic stages and paleogeographic changes in southeastern Peripannonian realm of Neogene and Quaternary. - XV Congress of CBGA., Geol. Soc. Greece, Sp. publ. 4/1: 69-73.

Marović, M., Toljić, M., Rundić, Lj., Milivojević, J. (2007): Neoalpine tectonics of Serbia. - Serbian Geological Society, Ser. Monographie, Belgrade.

Pavlović, P. S. (1890): Mediteranska fauna u Rakovici. - Geološki anali Balkanskoga poluostrva 2: 9-60. [in Serbian]

Pavlović, P. S. (1893): Prinove Geološkog zavoda. - Geološki anali Balkanskoga poluostrva 4: 186-191. [in Serbian]

Pavlović, P. (1903): Prinove Geološkog zavoda. - Geološki anali Balkanskoga poluostrva 6(1): 293-325. [in Serbian]

Pavlović, P. (1922): Prilozi za poznavanje tercijara u Srbiji. - Geološki anali Balkanskoga poluostrva 7(1): 42-50. [in Serbian]

Pavlović, P. (1923): Prilozi za poznavanje tercijara u Srbiji. -Geološki anali Balkanskoga poluostrva 7(2): 44-56. [in Serbian]

Pavlović, P. (1931): Prilozi za poznavanje tercijara u Srbiji. - Geološki anali Balkanskoga poluostrva 7(2): 104-113. [in Serbian]

Rundić, Lj. (2010): Geološki objekti i prirodni fenomeni kao integralni elementi geodiverziteta grada Beograda. -Rudarsko-geološki fakultet. [in Serbian]

Rundić, Lj., Knežević, S., Banjac, N., Ganić, M., Milovanović, D., Rabrenović, D. (2010): Geološki objekti i pojave kao integrali deo prirodne i kulturne baštine grada Beograda. - In: Banjac, N., Maran, A., Savić, Lj, Cukavac, M., Ganić, M. (eds.): Zbornik radova 15. Kongresa geologa Srbije sa medjunarodnim učešćem: 711-717.

Rundić, Lj., Ganić, M., Knežević, S., Soliman, A. (2011): Upper Miocene Pannonian sediments from Belgrade (Serbia): new evidence and paleoenvironmental considerations. - Geologica Carpathica 62(3): 267-278.

Rundić, Lj., Knežević, S., Ganić, M., Bradić, K. (2015): Novi podaci o stratigrafiji i tektonici Rakovičkog potoka (miocen okoline Beograda). In: I Kongres geologa u Bosni i Hercegovini sa međunarodnim učešćem, Tuzla, 21-23.10.2015: 48-49. - Udruženje/Udruga geologa u Bosni i Hercegovini, Knjiga sažetaka.

Rundić, Lj., Ganić, M., Knežević, S., Radivojević, D. (2017): Mio-Pliocene geodynamics and its stratigraphic consequences in the area of Avala Mt. (Belgrade, Serbia). In: $7^{\text {th }}$ International Workshop "Neogene of Central and South-Eastern Europe", 28-31 May 2017, Velika, Croatia, Abstract book: 57-58.

Schmid, S., Bernoulli, D., Fügenschuh, B., Matenco, L., Schefer, S., Schuster, R., Tischler, M., Ustaszewski, K. (2008): The Alpine-Carpathian-Dinaridic orogenic system: correlation and evolution of tectonic units. - Swiss Journal of Geosciences 101: 139-183.

Schwarchans, W., Bradić, K., Rundić, Lj. (2015): Fish-otoliths from the marine-brackish water transition from the Middle Miocene of the Belgrade area, Serbia. - Paläontologische Zeitschrift 89(4): 815-837. 
40 Rundić, LJ., KneŽEviĆ, S.: Miocene Fossiliferous sites of THE Avala MT.

Stepanović, B. (1938): Gornji miocen u Kamenom potoku kod sela Kumodraža Geološki anali Balkanskoga poluostrva 15: 51-102. [in Serbian]

Stevanović, P. (1951): Donji pliocen Srbije i susednih oblasti - Geološko paleontološka studija kaspi-brakičnih facija i produktivnih terena pontskog kata. - Srpska akademija nauka, Posebna izdanja CLXXXVII, Geološki institut 2. [in Serbian with German summary]

Stevanović, P. (1958): Potok Karagač ispod Avale - klasično mesto nalaska panonske faune mekušaca. - Zaštita prirode 12: 6-9. [in Serbian]

Stevanović, P. (1970): Paleogeografsko-ekoloske prinove iz tortona okoline Beograda. Glas SANU CCLXXVIII, Odeljenje prirodno-matematičkih nauka 33: 1-26 [in Serbian with German summary].

Stevanović, P. (1980): Osvrt na neotektoniku i paleogeografiju neogenih terena niske Šumadije. Geografski institut „Jovan Cvijić“ SANU, Zbornik radova 32: 19-50. [in Serbian]

Stevanović, P. (1985): Diskussion der Unterstufen Slavonien und Serbien. - In: Papp, A., Jambor, A., Steininger, F. F. (eds.): Chronostratigraphie und Neostratotypen, Miozän der Zentralen Paratethys, Pannonien M6: 82-85. Akadémiai Kiadó, Budapest, 7.

Ter Borgh, M., Vasiliev I., Stoica M., Knežević S., Matenco L., Krijgsman W., Rundić Lj., Cloething S. (2013): The isolation of the Pannonian basin (Central Paratethys): new constraints from magnetostratigraphy and biostratigraphy. Global and Planetary Change 103: 99-118.

Toljić, M. (2006): Geološka gradja centralne Vardarske zone izmedju Avale i Kosmaja. - Rudarsko-geološki fakultet Univerziteta u Beogradu (PhD Thesis, manuscr.) [In Serbian with English abstract].

Toljić, M. (2016): Tectonic evolution of the European margin and Neotethys suture zone in the region of Belgrade (Northern Šumadija-Serbia). - WSEAS Transactions on Environment and Development 12: 268-277.

\title{
ФОСИЛОНОСНИ ЛОКАЛИТЕТИ МИОЦЕНА НА ПОДРУЧЈУ АВАЛЕ (ОКОЛИНА БЕОГРАДА, СРБИЈА) И ЊИХОВ ЗНАЧАЈ
}

\author{
ЉУПКО РУНДИЋ, СЛОБОДАН КНЕЖЕВИЋ
}

\section{Р Е 3 И М Е}

Геодинамички процеси на простору јужног обода Панонског басена током миоцена условили су значајне (палео)географске промене у седиментационим басенима, које су утицале и на постепено 
смањење салинитета воде (море бракично море сланкасто језеро). Ове промене одразиле су се на организме који су живели у датим срединама као и на њихов начин живота. Представници појединих таксономских категорија успели су да се прилагоде варијацијама еколошких фактора и да опстану, док су други изумрли; квалитативни и квантитативни састав макро и микро фауне може се пратити на основу анализа сукцесија фосила.

Седименти средњег и горњег миоцена (пре око 16-5,3 милиона година), различитог литолошког састава, имају широко распрострањење на подручју Авале. Истраживања и сакупљања фосила, од којих прва датирају с краја 19. века, актуелна су и данас. Седименти по правилу садрже бројне и разноврсне представнике макро и микро фауне. Међу њима посебно се истичу представници асоцијација из средњег миоцена (баден и сармат) који су насељавали простор некадашњег Паратетиса, а откривени су на локалитетима Раковички поток, Лештане, Торлак, Кумодраж, долина Завојничке реке, Врчин. На овом подручју сакупљене су и фосилизоване алге, фораминифери, остракоди, мекушци, корали, бриозое, морски јежеви, крабе, као и отолити и делова вилица риба. У седиментима горњег миоцена остаци морских организама нису констатовани али су присутни бројни и разноврсни фосили ендемичне фауне некадашњег великог језера Панон. За науку најзначајнији фосилоносни локалитети налазе се у подножју Торлака, у Врчину, Зуцу, потоку Карагач, Белом потоку и потоку Конопљиште. Врло специфичне и релативно крупне љуштуре шкољака, пужева и остракода указују на повољне животне услове у оквиру „сланкастог“ каспибракичног језерског режима током горњег панона и понта.

Наведени локалитети значајни су не само са аспекта стратиграфско-палеонтолошкх истраживања, систематике, еволуције, тафономиje, палеогеографије, палеоекологије, реконструкције геодинамичких догађаја и промена током новије геолошке историје већ и као за науку и едукацију значајни објекти геодиверзитета и геонаслеђа шире околине града Београда. 